\title{
Antidepressant effect of methanol stem bark extract of Adansonia digitata: involvement of monoaminergic, nitric oxide and cholinergic pathways
}

\author{
Aishatu Shehu $^{1{ }^{(\mathbb{D}}}$, Mohammed Garba Magaji $^{1}{ }^{\circledR}$, Jamilu Ya'u $^{1}$, Abubakar Ahmed $^{\circledR}$ \\ ${ }^{1}$ Department of Pharmacology and Therapeutics, Ahmadu Bello University, Zaria, Kaduna State, Nigeria \\ ${ }^{2}$ Department of Pharmacognosy and Drug Development, Ahmadu Bello University, Zaria, Kaduna State, Nigeria
}

\section{A R T I C L E I N F 0}

Article Type:

Original Article

\section{Article History:}

Received: 31 October 2019

Accepted: 5 March 2020

\section{Keywords:}

Adansonia digitata

Depression

Nitric oxide

Monoaminergic activity

Cholinergic activity

\begin{abstract}
A B S T R A C T
Introduction: Hausa people of north-western Nigeria were reported to utilize the plant Adansonia digitata for the management of depressive illnesses in an ethno-botanical survey. Thus, this study aimed to establish the mechanism(s) via which methanol stem bark extract of A. digitata (MEAD) exhibits antidepressant activity in mice.

Methods: Antidepressant activity of MEAD was evaluated using tail suspension test (TST) at doses of 250, 500 and $1000 \mathrm{mg} / \mathrm{kg}$. For the mechanistic studies, mice were pre-treated with sulpiride $(50 \mathrm{mg} / \mathrm{kg})$, prazosin $(1 \mathrm{mg} / \mathrm{kg})$, yohimbine $(1 \mathrm{mg} / \mathrm{kg})$, metergoline $(1 \mathrm{mg} / \mathrm{kg})$, cyproheptadine $(3 \mathrm{mg} / \mathrm{kg})$, L-arginine $(50 \mathrm{mg} / \mathrm{kg})$, N omega-nitro-L-arginine (L-NNA; $50 \mathrm{mg} /$ $\mathrm{kg})$, atropine $(1 \mathrm{mg} / \mathrm{kg})$ and naloxone $(2 \mathrm{mg} / \mathrm{kg}) 15$ minutes prior to MEAD $(1000 \mathrm{mg} / \mathrm{kg})$ administration, then antidepressant activity was assessed using TST one hour later. Data were analysed using one-way ANOVA followed by Bonferroni post hoc test.

Results: The extract (at doses of 250, 500 and $1000 \mathrm{mg} / \mathrm{kg})$ significantly $(P<0.05)$ and dose dependently decreased the duration of immobility in the TST. Sulpiride ( $\mathrm{D}_{2}$ receptor antagonist), prazosin and yohimbine ( $\alpha_{1}$ and $\alpha_{2}$ receptor antagonists, respectively), metergoline and cyproheptadine (5- $\mathrm{HT}_{1}$ and $5-\mathrm{HT}_{2}$ receptor antagonists, respectively) significantly $(P<0.05)$ reversed the antidepressant effect of MEAD. On the other hand, L-NNA (NOS inhibitor) augmented the antidepressant effect of MEAD while L-arginine (nitric oxide substrate) had no effect on MEAD. However, atropine (muscarinic receptor antagonist) significantly $(P<0.01)$ augmented the antidepressant effect of MEAD.

Conclusion: The antidepressant activity of methanol stem bark extract of A. digitata was established to be via the monoaminergic, nitric oxide and cholinergic pathways.
\end{abstract}

Implication for health policy/practice/research/medical education:

This original research showed that Adansonia digitata stem bark extract possesses antidepressant activity that is mediated via monoaminergic, nitric oxide and cholinergic mechanisms. Hence, it might be very useful in treatment of resistant depression. Please cite this paper as: Shehu A, Magaji MG, Ya'u J, Ahmed A. Antidepressant effect of methanol stem bark extract of Adansonia digitata: involvement of monoaminergic, nitric oxide and cholinergic pathways. J Herbmed Pharmacol. 2021;10(1):8492. doi: 10.34172/jhp.2021.08.

\section{Introduction}

Depression is a serious devitalizing and severe disorder, significantly affecting the quality of life of a large population worldwide (1). It is a life-threatening and prevalent syndrome affecting divergent community settings (2). There are a lot of synthesized drugs utilized in treating the disorder, but most are associated with unwanted side effects, delayed onset of action and effective in only $50 \%$ of patients (3). The ineffectiveness of antidepressants and delayed onset of action have been linked to the involvement of several systems like the monoaminergic, nitric oxide, cholinergic and opioid pathways in the pathophysiology of depression (4-9). These factors made depressive disorders a complex and heterogeneous syndrome in therapy with only about one third of patients achieving remission (10). Thus, urges for development of 
new approaches to treatment of refractory depression that could target several pathways to elicit wider action $(11,12)$. Recently, antagonists of opioid receptors were reported to augment the antidepressant effect of drugs used in management of depression with additional benefits of lower toxicity profile (13). On the other hand, medicinal plants have been reportedly proven effective in treating depression in various models (14). Medicinal plants like Adansonia digitata has enjoyed patronage in management of depression locally in countries like Nigeria (15) and its antidepressant activity has been scientifically validated (16). The plant A. digitata L. (Malvaceae) is a tree native to African continent popularly known as Baobab. It has a lot of health benefits and its antibacterial, anti-plasmodial, anti-diarrhoeal, anti-asthmatic, blood supplement, antiviral, anti-oxidant and anti-inflammatory as well as antidepressant activities have been previously reported (17-21). The present study therefore aimed at evaluating the possible mechanism(s) of antidepressant activity of methanol stem bark extract of $A$. digitata.

\section{Materials and Methods}

Plant collection and extraction

Various parts of $A$. digitata including leaves, fruits and stem were collected in December 2016 and taken to Herbarium Section of Department of Botany, Ahmadu Bello University Zaria where it was identified and authenticated by Mr. Namadi Sanusi. A voucher specimen with number 2512 was deposited for future reference. The stem bark of the plant was taken to and dried in the Department of Pharmacognosy and Drug Development. It was then pulverised using mortar and pestle. About $1000 \mathrm{~g}$ of pulverised materials were extracted by soxhlet extraction with $5 \mathrm{~L}$ of methanol. The solution was concentrated on water bath $\left(45^{\circ} \mathrm{C}\right)$, after which the extract was stored in desiccator. Aqueous solution of the extract was freshly prepared for each study using distilled water.

\section{Animals}

Swiss Albino mice (both sex) were obtained from the Animal House Facility of Pharmacology and Therapeutics Department, Ahmadu Bello University Zaria. They were housed in improvised propylene cages under natural day and light cycle. The animals were fed on standard laboratory animal diet and water ad libitum. All experimental protocols were approved by the University Animal ethics committee with number ABUCAUC/2017/022.

\section{Drugs and chemicals}

The followings are some of the chemicals used for the experiment.

Imipramine (Tofranil GSK brand), diazepam (Roche, France), methanol (Fluka-Aldrich), metergoline (Tocris Bioscience), prazosin (Taiwan Healthcare), yohimbine (Tocris Bioscience), sulpiride (Shengheng Renyoung
Pharmaceuticals), cyproheptadine (Advacare Pharma), L-arginine (Puritan's Pride), L-NG-Nitroarginine (L-NNA) (Cayman Chemical)

Acute toxicity study

Median lethal dose $\left(\mathrm{LD}_{50}\right)$ was determined using Organization for Economic Co-operation and Development (OECD 425) guidelines in mice. Briefly, two groups each consisting of three mice were fasted 3 hours prior to dosing. Food was further withheld for 1-2 hours after administration of methanol stem bark extract of Adansonia digitata (MEAD). Limit test was conducted in two stages. In the first stage, each mouse was treated with the extract at a dose of $5000 \mathrm{mg} / \mathrm{kg}$ and observed for 48 hours. On survival, the second stage was carried out with two additional mice. Mice were observed each during the first 30 minutes of treatment and occasionally within 24 hours finally daily for 14 days.

Antidepressant studies

Tail suspension test in mice

Forty mice weighing 18-22 g were transported to laboratory and adapted for an hour. They were divided into five groups of eight mice each. The first, second and third groups were treated with graded doses MEAD (250, 500 and $1000 \mathrm{mg} / \mathrm{kg}$ ) an hour before test. The fourth and fifth groups were treated with distilled water $(10 \mathrm{~mL} /$ $\mathrm{kg}$ ) and imipramine $(15 \mathrm{mg} / \mathrm{kg})$, respectively. During the test, mice were suspended on the edge of the shelf $58 \mathrm{~cm}$ height placed on a table clipped by adhesive tape placed approximately $1 \mathrm{~cm}$ from the tip of the tail. Immobility was recorded over 6 minutes' period (22).

Mechanistic studies

Determining the possible involvement of the nitric oxide pathway

Fifty-six mice were grouped into 7 groups each of 8 mice. Groups 1, 2 and 3 were treated with distilled water (10 $\mathrm{mL} / \mathrm{kg}), \operatorname{MEAD}(1000 \mathrm{mg} / \mathrm{kg})$ and imipramine $(15 \mathrm{mg} /$ $\mathrm{kg}$ ) orally respectively. Groups 4 and 5 were pretreated with L-arginine (50 mg/kg, ip), a substrate of nitric oxide synthase, and groups 6 and 7 were pretreated with L-NNA $(50 \mathrm{mg} / \mathrm{kg}$, ip), a nitric oxide synthase enzyme inhibitor. Fifteen minutes later, the groups 4 and 5 were treated with MEAD (1000 mg/kg) and imipramine $(15 \mathrm{mg} / \mathrm{kg})$ orally, respectively. Also, groups 6 and 7 were treated with MEAD and imipramine orally, respectively. At the end of 1 hour, the mice in all groups were assessed using TST (23).

\section{Determining the involvement of dopaminergic pathway}

The possible involvement of dopaminergic pathway in the observed antidepressant activity of MEAD was determined using TST. Forty mice were grouped into five groups, each of 8 mice. The first, second and third groups were administered distilled water $(10 \mathrm{~mL} / \mathrm{kg})$, 
MEAD (1000 mg/kg) and imipramine (15 mg/kg) orally, respectively. Groups 4 and 5 were pretreated with sulpiride (50 mg/kg, ip), a dopamine $\mathrm{D}_{2} / \mathrm{D}_{3}$ receptors antagonist 15 minutes prior to administration of MEAD $(1000 \mathrm{mg} / \mathrm{kg})$ and imipramine $(15 \mathrm{mg} / \mathrm{kg})$ orally, respectively. One hour later, the mice in all groups were assessed using TST (24).

Assessing the involvement of serotonergic pathway Involvement of serotonergic system was assessed using TST in mice. Mice were grouped into seven groups with eight mice in each group. Groups 1, 2 and 3 were treated with distilled water $(10 \mathrm{~mL} / \mathrm{kg}), \operatorname{MEAD}(1000 \mathrm{mg} / \mathrm{kg})$ and imipramine $(15 \mathrm{mg} / \mathrm{kg})$ via oral route, respectively. Groups 4 and 5 were pretreated with metergoline $(1 \mathrm{mg} / \mathrm{kg}$, ip), a serotonin $5-\mathrm{HT}_{1}$ receptor antagonist, and the groups 6 and 7 were pretreated with cyproheptadine ( $3 \mathrm{mg} / \mathrm{kg}$, ip), a serotonin $5-\mathrm{HT}_{2}$ receptor antagonist. Fifteen minutes later, the mice in groups 4 and 6 were treated with MEAD $(1000 \mathrm{mg} / \mathrm{kg}$ ), and the groups 5 and 7 were treated with imipramine $(15 \mathrm{mg} / \mathrm{kg})$ orally. One hour after treatment, the mice in all groups were subjected to TST.

Investigating the possible involvement of noradrenergic system

To investigate the possible involvement of the noradrenergic system in the antidepressant action of MEAD, 56 mice grouped into 7 groups of 8 mice each were used. The first, second and third groups received distilled water $(10 \mathrm{~mL} / \mathrm{kg}), \operatorname{MEAD}(1000 \mathrm{mg} / \mathrm{kg})$ and imipramine $(15 \mathrm{mg} / \mathrm{kg})$ orally, respectively. The fourth and fifth groups were pretreated with prazosin $(1 \mathrm{mg} /$ $\mathrm{kg}$, ip), an al adrenergic antagonist, 15 minutes prior to administration of MEAD (1000 mg/kg) and imipramine (15 mg/kg) orally, respectively. The sixth and seventh groups were pretreated with yohimbine (1 mg/kg, ip), an a2 adrenergic antagonist, 15 minutes later, MEAD (1000 $\mathrm{mg} / \mathrm{kg})$ and imipramine $(15 \mathrm{mg} / \mathrm{kg})$ were administered orally, respectively. Mice in all the groups were assessed one hour later using TST.

Investigating the possible involvement of cholinergic system To investigate the possible involvement of the cholinergic system in the antidepressant action of MEAD, 40 mice, divided into 5 groups of 8 mice each, were used. The first, second and third groups received distilled water (10 mL/kg), MEAD (1000 mg/kg) and imipramine (15 $\mathrm{mg} / \mathrm{kg}$ ) orally, respectively. The fourth and fifth groups were pretreated with atropine $(1 \mathrm{mg} / \mathrm{kg}$, ip), a muscarinic receptor antagonist, 15 minutes prior to administration of MEAD (1000 mg/kg) and imipramine $(15 \mathrm{mg} / \mathrm{kg})$ orally respectively. Mice in all the groups were assessed one hour later using TST.

Investigating the possible involvement of opioidergic system To investigate the possible involvement of the opioidergic system in the antidepressant action of MEAD, 40 mice, divided into 5 groups of 8 mice each, were used. The first, second and third groups received distilled water (10 mL/kg), MEAD (1000 mg/kg) and imipramine (15 $\mathrm{mg} / \mathrm{kg}$ ) orally, respectively. The fourth and fifth groups were pretreated with naloxone ( $2 \mathrm{mg} / \mathrm{kg}$, ip), an opioid receptor antagonist, 15 minutes prior to administration of MEAD (1000 mg/kg) and imipramine (15 mg/kg) orally, respectively. Mice in all the groups were assessed one hour later using TST.

\section{Statistical analysis}

Values were expressed as mean \pm SEM and differences analysed by one-way analysis of variance (ANOVA) followed by Bonferroni post hoc test using SPSS version 23.0. A value of $P \leq 0.05$ was considered significant.

\section{Results}

Acute toxicity $\left(\mathrm{LD}_{50}\right)$ of methanol stem bark extract of Adansonia digitata

The $\mathrm{LD}_{50}$ of methanol stem bark extract of $A$. digitata was estimated to be greater than $5000 \mathrm{mg} / \mathrm{kg}$ orally in mice.

Antidepressant effect of methanol stem bark extract of Adansonia digitata

In the tail suspension test (TST), the immobility time was noted within the first 5 min (Figure 1). The methanol extract of $A$. digitata significantly $(P<0.01)$ and dose dependently decreased the immobility time as compared to the distilled water treated group. A significant $(P<0.01)$ reduction in immobility time was also observed in the imipramine treated group.

Mechanistic studies

Involvement of nitric oxide pathway

MEAD (1000 mg/kg) and imipramine (15 mg/kg) significantly $(P<0.01)$ decreased the immobility time as compared to the distilled water treated group. The reduction of duration immobility by both extract and imipramine was not reversed by the L-arginine (Figure 2). Pre-treatment with L-NNA significantly $(P<0.01)$

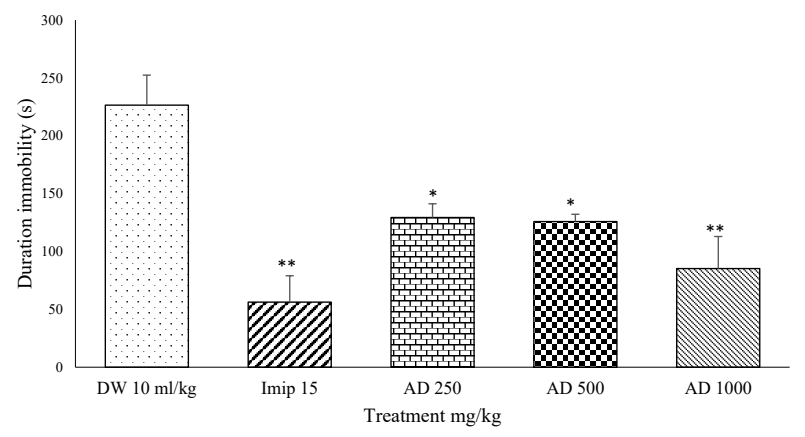

Figure 1. Effect of methanol stem bark extract of Adansonia digitata on the TST. Each column represents the immobility time of mice expressed as mean \pm S.E.M., $\mathrm{n}=8 .{ }^{*} P<0.01,{ }^{* *} P<0.001$ as compared to the distilled water group. $\mathrm{DW}=$ distilled water, $\mathrm{AD}=A$. digitata, Imip $=$ Imipramine. 


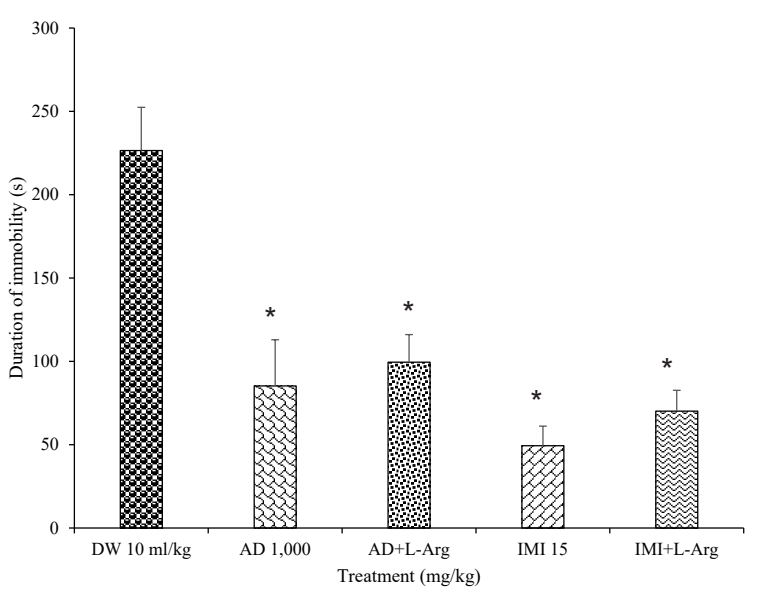

Figure 2. Effect of L-arginine on antidepressant activity of methanol stem bark extract of Adansonia digitata in the mouse tail suspension test. Each column represents the mean $\pm \mathrm{SEM}, \mathrm{n}=8$. Data analysis was performed using one-way ANOVA followed by Bonferroni post hoc test, ${ }^{\star} P \leq 0.01$, significantly different from DW group; $\mathrm{AD}=$ Adansonia digitata $(1000 \mathrm{mg} /$ $\mathrm{kg}, p o) ; \mathrm{IMI}=$ Imipramine $(15 \mathrm{mg} / \mathrm{kg}, p o) ; \mathrm{L}-A r g=\mathrm{L}$-arginine $(50 \mathrm{mg} / \mathrm{kg}$, ip); DW= Distilled water.

augmented the antidepressant effect observed with methanol bark extract of $A$. digitata or imipramine alone. As compared to the distilled water group, L-NNA (nitric oxide synthase enzyme inhibitor) pretreated group showed greater antidepressant-like effect compared with the extract or imipramine alone (Figure 3).

\section{Involvement of dopaminergic system}

The extract and imipramine significantly $(P<0.01)$ reduced the duration immobility as compared to distilled water treated group. However, sulpiride significantly $(P<0.01)$ reversed the effect of both extract and imipramine (Figure 4).

\section{Involvement of noradrenergic system}

There was significant $(P<0.001)$ reduction in immobility duration in the mice treated with either methanol stem bark extract of $A$. digitata, imipramine or imipramine pre-treated with prazosin ( $\alpha_{1}$ adrenergic antagonist) as compared to the distilled water group. The reduction in duration immobility was insignificant in extract pretreated with prazosin treated group as compared to the distilled water treat mice (Figure 5). There was no significant difference between distilled water treated and the groups treated with the extract, pre-treated with yohimbine ( $\alpha 2$ adrenergic antagonist) and imipramine pre-treated with yohimbine. However, there was a significant increase $(P<0.01)$ in duration immobility in imipramine pre-treated with yohimbine as compared to imipramine only treated group (Figure 6).

\section{Involvement of serotonergic system}

The methanol extract and imipramine significantly

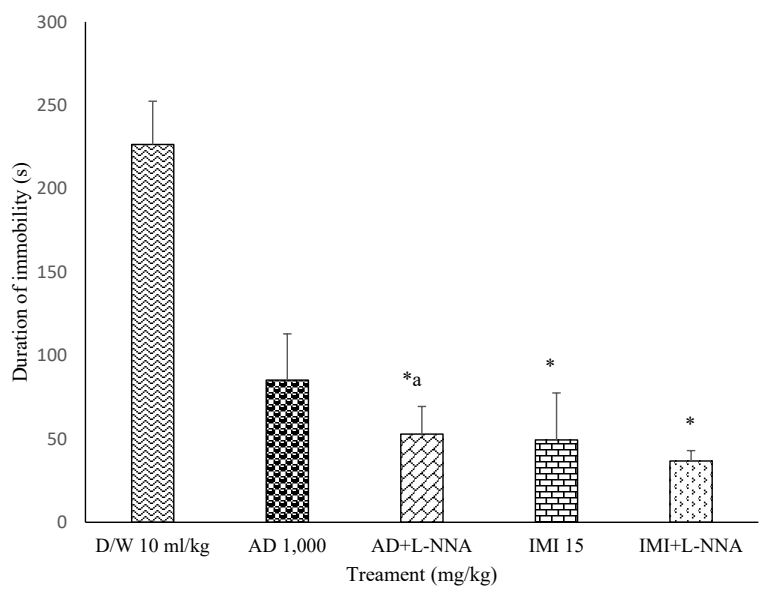

Figure 3. Effect of L-NNA on antidepressant activity of methanol stem bark extract of Adansonia digitata in the mouse tail suspension test. Each column represents the mean $\pm S E M, n=8$. Data analysis was performed using One-way ANOVA followed by Bonferroni post hoc test, ${ }^{*} P \leq 0.01$, significantly different from DW group; ${ }^{a} P \leq 0.01$ significantly different from $A D$-treated group; $A D=$ Adansonia digitata $(1000 \mathrm{mg} / \mathrm{kg}, \mathrm{po}) ; \mathrm{IMI}=$ Imipramine (15 mg/kg, po); L-NNA= L-Nitro N-Arginine $(50 \mathrm{mg} / \mathrm{kg}, i p)$; $\mathrm{DW}=$ Distilled water.

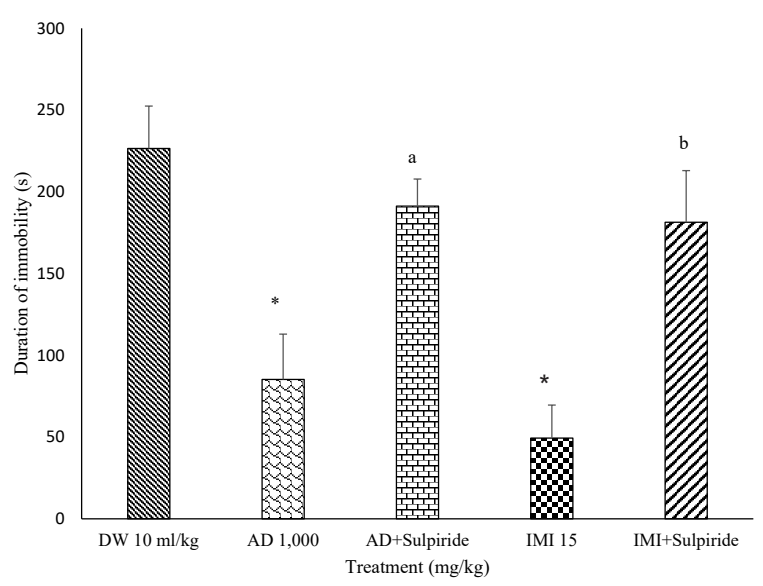

Figure 4. Effect of sulpiride on antidepressant activity of methanol stem bark extract of Adansonia digitata in the mouse tail suspension test. Each column represents the mean $\pm S E M, n=8$. Data was analysed using oneway ANOVA followed by Bonferroni post hoc test, * $P \leq 0.001$ significantly different from $D W$ treated group; ${ }^{a, b} P \leq 0.01$ significantly different from $A D$ and IMI treated groups respectively; $\mathrm{AD}=$ Adansonia digitata $(1000 \mathrm{mg} /$ $\mathrm{kg}, p o) ; \mathrm{IMI}=$ Imipramine (15 mg/kg, po); DW = Distilled water $(10 \mathrm{~mL} / \mathrm{kg}$, po), Sulpiride (50 mg/kg, ip)

$(P<0.01)$ decreased the duration of immobility as compared to the distilled water group. Metergoline (5- $\mathrm{HT}_{1}$ receptor antagonist) insignificantly increased the immobility time. Conversely, metergoline did not significantly alter the imipramine immobility time (Figure $7)$. The methanol extract and imipramine significantly $(P<0.01)$ decreased the duration of immobility as compared to the distilled water group. On the other hand, cyproheptadine insignificantly increased the duration 


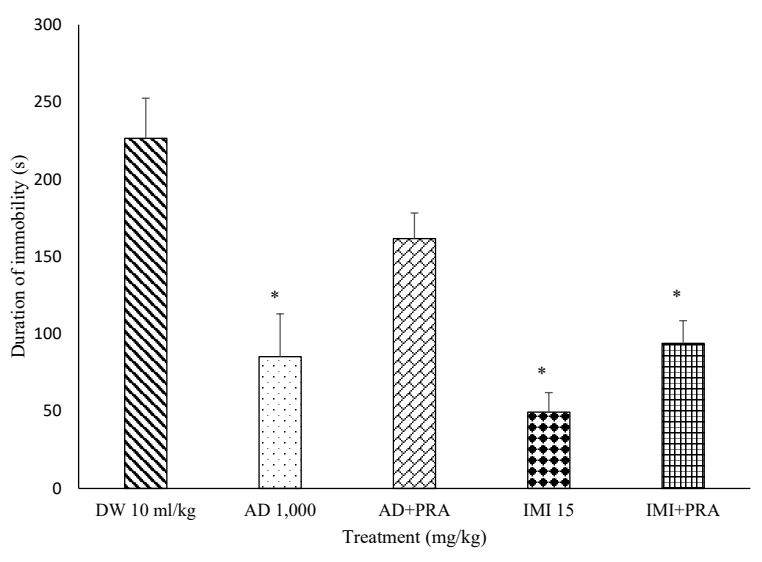

Figure 5. Effect of prazosin on antidepressant activity of methanol stem bark extract of Adansonia digitata in the mouse tail suspension test. Each column represents the mean $\pm S E M, n=8$. Data analysis was performed using one-way ANOVA followed by Bonferroni post hoc test, ${ }^{*} P \leq 0.01$ significantly different from DW group; $\mathrm{AD}=$ Adansonia digitata $(1000 \mathrm{mg} /$ $\mathrm{kg}, \mathrm{po}) ; \mathrm{IMI}=$ Imipramine $(15 \mathrm{mg} / \mathrm{kg}) ; \mathrm{PRA}=$ Prazosin $(1 \mathrm{mg} / \mathrm{kg}), \mathrm{DW}=$ Distilled water $(10 \mathrm{~mL} / \mathrm{kg}, \mathrm{po})$.

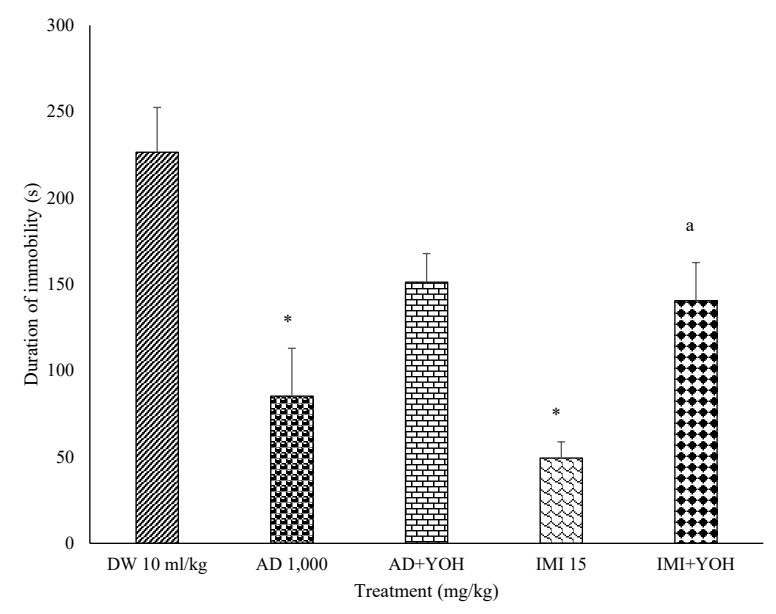

Figure 6. Effect of yohimbine on antidepressant activity of methanol stem bark extract of Adansonia digitata in the mouse tail suspension test. Each column represents the mean \pm SEM, $n=8$. Data was analysed using oneway ANOVA followed by Bonferroni post hoc test, ${ }^{*} P \leq 0.001$ significantly different from DW treated group; ${ }^{a} P \leq 0.01$ significantly different from Imipramine treated group; $\mathrm{AD}=$ Adansonia digitata $(1000 \mathrm{mg} / \mathrm{kg}, \mathrm{po}) ; \mathrm{IMI}$ $=$ Imipramine, $\mathrm{DW}=$ Distilled water $(10 \mathrm{~mL} / \mathrm{kg}, p o), \mathrm{YOH}=$ Yohimbine $(1$ $\mathrm{mg} / \mathrm{kg}$, ip).

immobility of the extract with no effect of the imipramine (Figure 8).

\section{Involvement of cholinergic pathway}

Pretreatment with atropine significantly $(P<0.01)$ decreased the duration of immobility of mice treated with methanol stem bark extract of $A$. digitata $(1000 \mathrm{mg} /$ $\mathrm{kg}$ ). On the other hand, atropine pretreatment did not significantly change the duration of immobility of mice treated with imipramine (Figure 9).

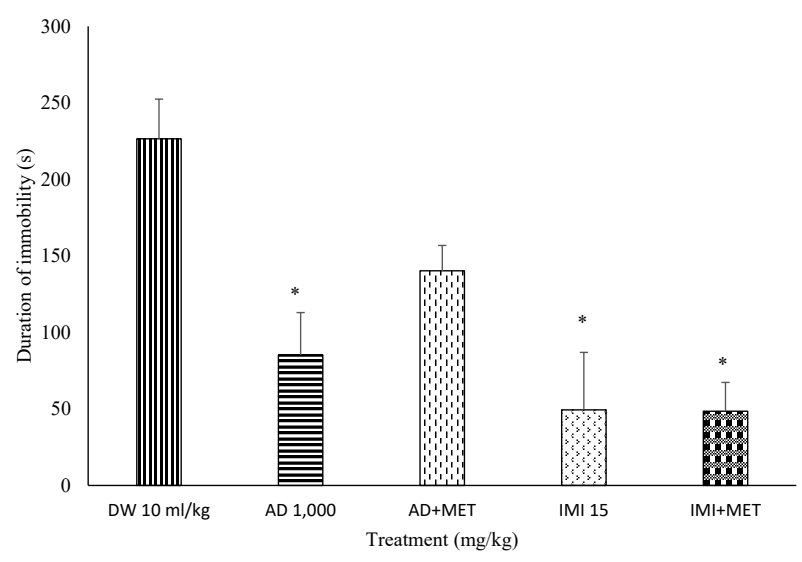

Figure 7. Effect of metergoline on antidepressant activity of methanol stem bark extract of Adansonia digitata in the mouse tail suspension test. Each column represents the mean $\pm S E M, n=8$. Data was analysed using One-way ANOVA followed by Bonferroni post hoc test, ${ }^{*} P \leq 0.001$ significantly different from DW group; $A D=$ Adansonia digitata $(1000 \mathrm{mg} /$ $\mathrm{kg}, p o) ; \mathrm{IMI}=$ Imipramine $(15 \mathrm{mg} / \mathrm{kg}, p o), \mathrm{DW}=$ Distilled water $(10 \mathrm{~mL} / \mathrm{kg}$, po), MET = Metergoline $(1 \mathrm{mg} / \mathrm{kg}, i p)$

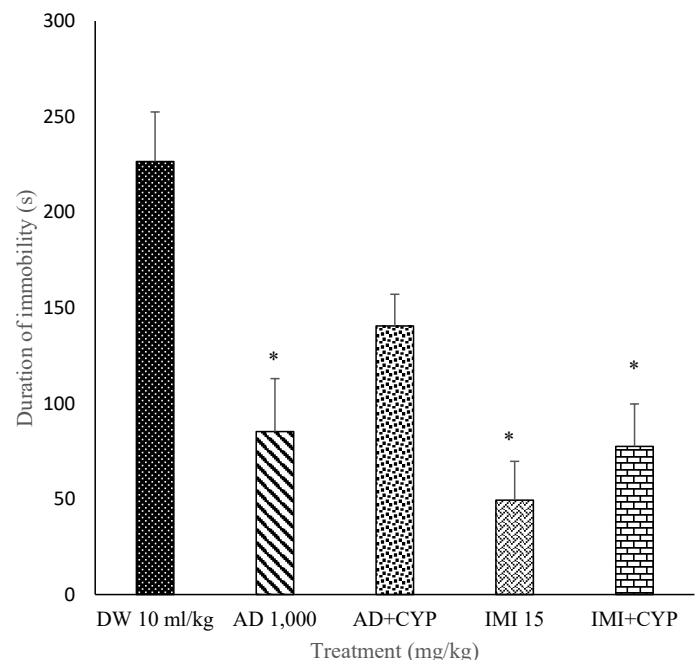

Figure 8. Effect of cyproheptadine on antidepressant activity of methanol stem bark extract of Adansonia digitata in the mouse tail suspension test. Each column represents the mean \pm SEM, $n=8$. Data was analysed using one-way ANOVA followed by Bonferroni post hoc test, ${ }^{*} P \leq 0.001$ significantly different from $\mathrm{DW}$ group; $\mathrm{AD}=$ Adansonia digitata $(1000 \mathrm{mg} /$ $\mathrm{kg}, p o) ; \mathrm{IMI}=$ Imipramine $(15 \mathrm{mg} / \mathrm{kg}, p o), \mathrm{DW}=$ Distilled water $(10 \mathrm{~mL} / \mathrm{kg}$, po), CYP = Cyproheptadine $(3 \mathrm{mg} / \mathrm{kg}, i p)$.

\section{Involvement of opioid pathway}

Pre-treatment with naloxone non-significantly decreased the duration of immobility of mice treated with methanol stem bark extract of $A$. digitata $(1000 \mathrm{mg} / \mathrm{kg})$ and/or imipramine $15 \mathrm{mg} / \mathrm{kg}$ (Figure 10).

\section{Discussion}

The plant A. digitata is widely used in the treatment of depression in traditional medicine (15) which has been validated scientifically (16). The present study attempted to provide the possible mechanisms for its antidepressant 


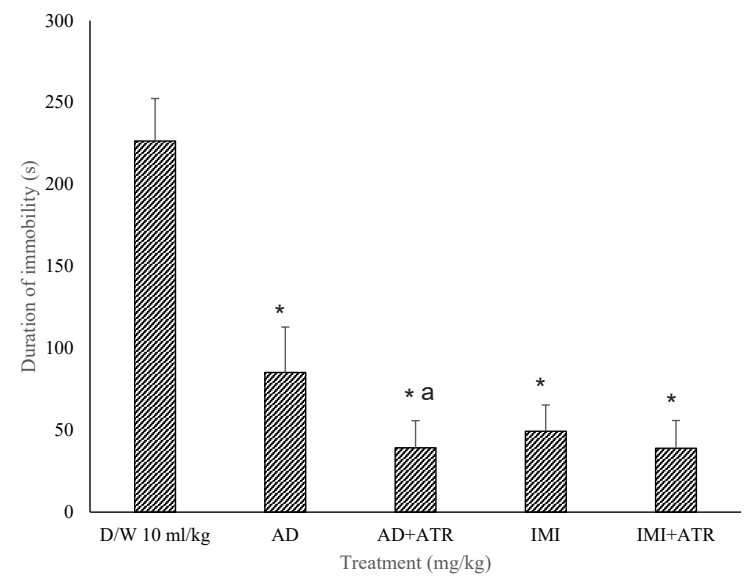

Figure 9. Effect of atropine on antidepressant activity of methanol stem bark extract of Adansonia digitata in the mouse tail suspension test. Data are mean \pm SEM, $n=8$, analysed using One-way ANOVA followed by Bonferroni post hoc test, ${ }^{*} P \leq 0.001$ significantly different from DW group; ${ }^{a} P \leq 0.001$ significantly different from $A D$ treated group; $A D=$ Adansonia digitata (1, $000 \mathrm{mg} / \mathrm{kg}, p o) ; \mathrm{IMI}=$ Imipramine $(15 \mathrm{mg} / \mathrm{kg}, p o)$, $\mathrm{DW}=$ Distilled water $(10 \mathrm{~mL} / \mathrm{kg}, p o)$, ATR $=$ Atropine $(1 \mathrm{mg} / \mathrm{kg}, i p)$.

activity. The results of the present study demonstrated that methanol stem bark extract of $A$. digitata has antidepressant-like effects. Moreover, the findings in this study showed the involvement of monoaminergic, nitric oxide and cholinergic pathways in the antidepressant effect of the extract.

There are many antidepressants agents available but are faced with one shortcoming or the other. As part of the target for future promising and novel antidepressants is the manipulations of nitric oxide pathway (12). An attempt was also made in this study to assess the involvement of nitric oxide pathway. Nitric oxide plays a regulatory role in behaviour, cognition, learning and memory (25). It is synthesized in the brain from a precursor L-arginine via the activities of an enzyme nitric oxide synthase (NOS) following excitatory amino acids activation of NMDA receptors (26). There are two major targets in this pathway, the first is utilization of nitric oxide synthase substrate like L- arginine to either reverse the antidepressantlike effect or worsen depression. The second target is utilization of the nitric oxide synthase inhibitor such as 1-(2-trifluoromethylphenyl)-imidazole to either augment antidepressant-like activity or produce antidepressant like-effect (27). Pre-treatment with L-arginine did not reverse the antidepressant activity of MEAD in this study. On the other hand, pre-treatment with NOS inhibitor L-NNA augmented the antidepressant activity of MEAD. NOS activity has been reported to be involved in the mechanism action of antidepressants such as the selective serotonin reuptake inhibitor (SSRI) (28). SSRIs were mentioned to inhibit in vitro NOS activity with a resultant decrease in plasma nitrite and nitrate levels in depression. Additionally, NOS inhibitor was also reported to increase

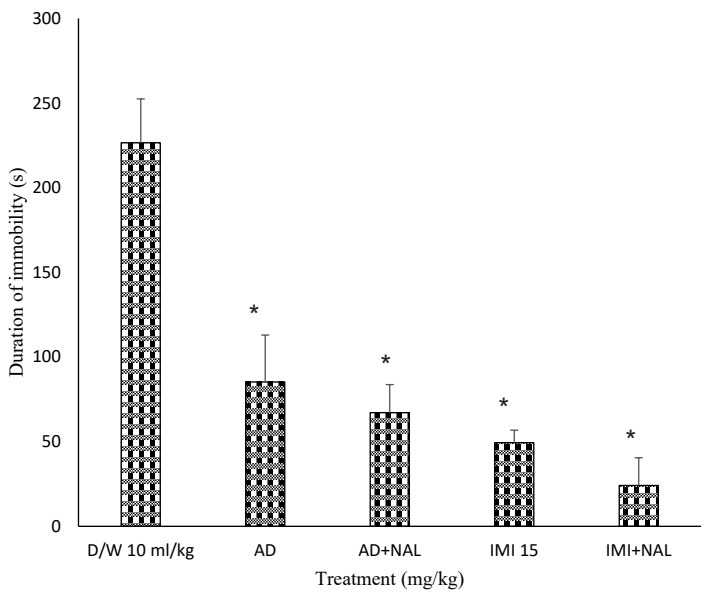

Figure 10. Effect of naloxone on antidepressant activity of methanol stem bark extract of Adansonia digitata in the mouse tail suspension test. Each column represents the mean $\pm S E M, n=8$. Data was analysed using one-way ANOVA followed by Bonferroni post hoc test, * $=P \leq 0.001$ significantly different from DW group; $A D=$ Adansonia digitata $(1000 \mathrm{mg} /$ $\mathrm{kg}, p o) ; \mathrm{IMI}=$ Imipramine $(15 \mathrm{mg} / \mathrm{kg}, \mathrm{po}), \mathrm{DW}=$ Distilled water $(10 \mathrm{~mL} / \mathrm{kg}$, po), NAL = Naloxone $(2 \mathrm{mg} / \mathrm{kg}, i p)$.

serotonin levels in hippocampus following systemic administration (29). This showed that antidepressantlike effects of NOS inhibitors may have link to alterations that occur in brain serotonin levels. The antidepressant effect of MEAD may be due to its ability increase brain serotonin levels.

An effort was made to determine the involvement of dopamine $\mathrm{D}_{2} / \mathrm{D}_{3}$ receptors in the antidepressant effects of MEAD (30). Sulpiride is a derivative of benzylamide highly selective for central and peripheral dopamine $\mathrm{D}_{2}$ and $\mathrm{D}_{3}$ receptors $(31)$. It has both typical and atypical antipsychotic properties (32), as well as prolactin stimulatory action (33). The ability of sulpiride to reverse the antidepressant activity of MEAD suggests that its activity might be mediated via the dopaminergic pathway, specifically via $\mathrm{D}_{2} / \mathrm{D}_{3}$ receptors. This finding is corroborated by the reversal of the antidepressant activity of imipramine by sulpiride. Imipramine is known to act via dopamine $\mathrm{D}_{2}$ receptors (34) and this was evidently observed in this study.

Metergoline, cyproheptadine, prazosin and yohimbine were also used respectively to investigate the involvement of serotonergic, histaminergic, $\alpha_{1}$ and $\alpha_{2}$ adrenergic receptor pathways in the antidepressant activity of the extract. Metergoline reversed the antidepressant activity of the extract indicating the involvement of serotonergic pathways. Imipramine on the other hand rarely acts via serotonergic pathway in its antidepressant activity, thus metergoline had no effect on its effect. Metergoline is a potent antagonist of 5-HT1 receptor antagonist. The $5-\mathrm{HT}_{1}$ receptor is one of the most studied out of the fourteen serotonergic receptors (35) and useful with regards to antidepressant actions (12). 
Cyproheptadine is also a serotonin (5- $\mathrm{HT}_{2}$ receptor) antagonist that causes sedation and reverse the antidepressant effect of the SSRIs but not tricyclic antidepressants (36). More so, it is an antihistamine used for allergic rhinitis, conjunctivitis and certain skin reactions in addition to its benefits in serotonin syndrome therapy (37). $5-\mathrm{HT}_{2}$ receptors especially the $5-\mathrm{HT}_{2 \mathrm{~A}}$ and $5-\mathrm{HT}_{2 \mathrm{c}}$ subtypes are involved in neurochemical changes elicited by antidepressants (38). A clear correlation was established between $5-\mathrm{HT}_{2}$ receptor polymorphism and suicidal attempts in severely depressed patients (39) which ascertained the involvement of $5-\mathrm{HT}_{2}$ receptors in depression. In this study, pre-treatment with cyproheptadine reversed the antidepressant-like effect of MEAD. The involvement of $5-\mathrm{HT}_{2}$ receptor in the mechanism action of MEAD is an indication that it might be useful in severely depressed individuals with suicidal ideation.

Additionally, pre-treatment with prazosin and yohimbine resulted in the reversal of the antidepressant activity of MEAD. Unlike the extract, the antidepressant effect of imipramine was reversed by yohimbine but not prazosin. Prazosin and yohimbine are antagonist of $\alpha_{1}$ and $\alpha_{2}$ adrenergic receptors, respectively $(40,41)$. There is evidence of increase in cortisol response to the $a_{2}$-antagonist yohimbine which in turn stimulates hypothalamo-pituitary- adrenal (HPA) axis (42). Yohimbine is also reported to enhance dopamine turnover and suppress serotonin turnover of brain striatum. Furthermore, it reduces firing of serotonergic neurones in raphe nuclei (43). The ability of yohimbine to reverse the antidepressant effect of methanol extract of $A$. digitata further affirms the involvement of dopaminergic and serotonergic pathways in eliciting the antidepressant action. The antidepressant activity of MEAD may also be due to the suppression of HPA-axis activity which is usually hyperactivated in depression. Several researches have also proposed the ability of yohimbine to abolish antidepressant activity of imipramine (44) as clearly confirmed in this study.

Prazosin is an alpha-adrenergic blocker used as antihypertensive agent, in heart failure and Raynaud's syndrome. It is also used in prostate hyperplasia and in scorpion stings with depression as one of its commonest side effects (45). Many clinical researchers reported alterations in brain alpha-1 noradrenergic neurotransmission to be associated with some of the symptoms observed in depression and these alterations were linked to increased corticosteroid secretions $(46,47)$. In this study, prior administration of prazosin resulted in the reversal of the antidepressant activity of MEAD. This showed the involvement of $\alpha_{1}$ adrenergic receptors in antidepressant action of MEAD probably via increase in $\alpha_{1}$ noradrenergic neurotransmission or via decrease in corticosteroid secretions. On the other hand, prazosin does not alter the effect of imipramine as previously reported (48).

Atropine is an anticholinergic or an antimuscarinic agent that antagonizes the muscarinic actions of acetylcholine and other choline esters (49). Atropine augmented the antidepressant-like effect of MEAD. This indicated the involvement of cholinergic pathways in the antidepressant activity of MEAD. Acetylcholine is a neurotransmitter involved in direct neurotransmission in the autonomic parasympathetic nervous system. According to cholinergic-adrenergic hypothesis, depression is a clinical manifestation of acetylcholine dominance. Consequently, anticholinergic drugs were continually investigated as potential treatments for depression which led to the establishment of dosage dependency of scopolamine as antidepressant (50). Thus, the antidepressant effect of MEAD could be due to its ability to antagonize the effect of acetylcholine dominance.

Naloxone is an antagonist of opioid receptors. Major depressive disorder has an additional etiology to include opioid pathway which causes opioids to be considered a therapeutic approach in the treatment of MDD (51). Opioid antagonists were reported to be promising in treatment of resistant depression (13). Kappa opioid receptor was reported to be involved in the stress system implicated in depression pathophysiology and other psychiatric disorders characterized by reward dysfunction (52-54). Pre-treatment with naloxone augmented the antidepressant activity of MEAD, indicating the involvement of opioidergic system in its effect. Moreover, the opioid antagonist naloxone against all opioid receptors was also found to have antidepressant effect in the learned helplessness and depressive models (55) as evidenced in this study.

\section{Conclusion}

With regards to the finding in this research, it was demonstrated that methanol stem bark extract of A. digitata possessed antidepressant activity which was further found to be mediated via dopaminergic, serotonergic, adrenergic, cholinergic and nitric oxide pathways. Thus, this will render the plant $A$. digitata effective in the treatment of resistant depressive cases.

\section{Acknowledgments}

The technical help of Mr Bashir Shehu and Mr Abubakar Balarabe of the Department of Pharmacology and Therapeutics, ABU Zaria is acknowledged.

\section{Authors' contributions}

All the authors contributed to data collection and preparation of the manuscript. The first draft was prepared by AS and MGM. All authors read the final version and confirmed for the publication. 


\section{Conflict of interests}

The authors declared no conflict of interests.

\section{Ethical considerations}

Ethical approval was obtained from Ahmadu Bello University Committee on Animal Use and Care (ABUCAUC/2017/022).

\section{Funding/Support}

None.

\section{References}

1. Gerhard DM, Wohleb ES, Duman RS. Emerging treatment mechanisms for depression: focus on glutamate and synaptic plasticity. Drug Discov Today. 2016;21(3):454-64. doi: 10.1016/j.drudis.2016.01.016.

2. Rabiei Z, Naderi S, Rafieian-Kopaei M. Study of antidepressant effects of grape seed oil in male mice using tail suspension and forced swim tests. Bangladesh J Pharmacol. 2017;12(4):397402. doi: 10.3329/bjpv12i4.33520.

3. Khan D, Fernando P, Cicvaric A, Berger A, Pollak A, Monje FJ, et al. Long-term effects of maternal immune activation on depression-like behavior in the mouse. Transl Psychiatry. 2014;4(2):e363. doi: 10.1038/tp.2013.132.

4. Duman RS, Heninger GR, Nestler EJ. A molecular and cellular theory of depression. Arch Gen Psychiatry. 1997;54(7):597606. doi: 10.1001/archpsyc.1997.01830190015002.

5. Harkin AJ, Bruce KH, Craft B, Paul IA. Nitric oxide synthase inhibitors have antidepressant-like properties in mice. 1. Acute treatments are active in the forced swim test. Eur J Pharmacol. 1999;372(3):207-13. doi: 10.1016/s00142999(99)00191-0.

6. Cryan JF, Markou A, Lucki I. Assessing antidepressant activity in rodents: recent developments and future needs. Trends Pharmacol Sci. 2002;23(5):238-45. doi: 10.1016/ s0165-6147(02)02017-5.

7. Harkin A, Connor TJ, Walsh M, St John N, Kelly JP. Serotonergic mediation of the antidepressant-like effects of nitric oxide synthase inhibitors. Neuropharmacology. 2003;44(5):616-23. doi: 10.1016/s0028-3908(03)00030-3.

8. Celada P, Puig M, Amargós-Bosch M, Adell A, Artigas F. The therapeutic role of 5-HT1A and 5-HT2A receptors in depression. J Psychiatry Neurosci. 2004;29(4):252-65.

9. Ulak G, Mutlu O, Tanyeri P, Komsuoglu FI, Akar FY, Erden BF. Involvement of serotonin receptor subtypes in the antidepressant-like effect of TRIM in the rat forced swimming test. Pharmacol Biochem Behav. 2010;95(3):30814. doi: 10.1016/j.pbb.2010.02.006.

10. Trivedi MH, Rush AJ, Wisniewski SR, Nierenberg AA, Warden D, Ritz L, et al. Evaluation of outcomes with citalopram for depression using measurement-based care in STAR ${ }^{\star} \mathrm{D}$ : implications for clinical practice. Am J Psychiatry. 2006;163(1):28-40. doi: 10.1176/appi.ajp.163.1.28.

11. Mutlu O, Ulak G, Laugeray A, Belzung C. Effects of neuronal and inducible NOS inhibitor 1-[2-(trifluoromethyl) phenyl] imidazole (TRIM) in unpredictable chronic mild stress procedure in mice. Pharmacol Biochem Behav. 2009;92(1):827. doi: 10.1016/j.pbb.2008.10.013.

12. Mutlu O, Ulak G, Celikyurt IK, Akar FY, Erden F. New Approaches for the Therapy of Treatment Refractory Depression. In: Rossi G, ed. Psychology: Selected Papers.
InTech; 2012. doi: 10.5772/37974. Available from: https:// www.intechopen.com/books/psychology-selected-papers/ treatment-refractory-depression accessed 20th January, 2018.

13. Peckham AM, De La Cruz A, Dufresne RL. Kappa opioid receptor antagonism: are opioids the answer for treatment resistant depression? Ment Health Clin. 2018;8(4):175-83. doi: $\quad 10.9740 / \mathrm{mhc} .2018 .07 .175$.

14. Lee G, Bae H. Therapeutic effects of phytochemicals and medicinal herbs on depression. Biomed Res Int. 2017;2017:6596241. doi: 10.1155/2017/6596241.

15. Shehu A, Magaji MG, Yau J, Ahmed A. Ethno-botanical survey of medicinal plants used for the management of depression by Hausa tribes of Kaduna State, Nigeria. J Med Plants Res. 2017;11(36):562-57. doi: 10.5897/jmpr2017.6462.

16. Shehu A, Magaji MG, Yau J, Mahmud B, Ahmed A. Antidepressant effect of methanol stem bark extract of Adansonia digitata L. (Malvaceae) in mice. Trop J Nat Prod Res. 2018;2(2):87-91. doi: 10.26538/tjnpr/v2i2.6.

17. Rahul J, Jain MK, Singh SP, Kamal RK, Anuradha, Naz A, et al. Adansonia digitata L. (baobab): a review of traditional information and taxonomic description. Asian Pac J Trop Biomed. 2015;5(1):79-84. doi: 10.1016/S22211691(15)30174-X.

18. Yusha’u M, Hamza MM, Abdullahi N. Antibacterial activity of Adansonia digitata stem bark extracts on some clinical bacterial isolates. Int J Biomed Health Sci. 2010;6(3):129-35.

19. Nguta JM, Mbaria JM, Gakuya DW, Gathumbi PK, Kiama SG. Antimalarial herbal remedies of Msambweni, Kenya. J Ethnopharmacol. 2010;128(2):424-32. doi: 10.1016/j. jep.2010.01.033.

20. De Caluwé, E, Halamová K, Van Damme P. Baobab (Adansonia digitata L.): a review of traditional uses, phytochemistry and pharmacology. In: Juliani HR, Simon JE, Ho CT, eds. African Natural Plant Products: New Discoveries and Challenges in Chemistry and Quality. Washington, DC: American Chemical Society; 2009. p. 51-84. vol 1021, Chapter 4.

21. Tapsoba H, Deschamps JP. Use of medicinal plants for the treatment of oral diseases in Burkina Faso. J Ethnopharmacol. 2006;104(1-2):68-78. doi: 10.1016/j.jep.2005.08.047.

22. Steru L, Chermat R, Thierry B, Simon P. The tail suspension test: a new method for screening antidepressants in mice. Psychopharmacology (Berl). 1985;85(3):367-70. doi: 10.1007/ bf00428203

23. Zheng M, Li Y, Shi D, Liu C, Zhao J. Antidepressant-like effects of flavonoids extracted from Apocynum venetum leaves in mice: the involvement of monoaminergic system in mice. Afr J Pharm Pharmacol. 2014;8(29):765-74. doi: 10.5897/ajpp12.641.

24. Gay BM, Prigol M, Stein AL, Nogueira CW. Antidepressantlike pharmacological profile of 3-(4-fluorophenylselenyl)-2,5diphenylselenophene: involvement of serotonergic system. Neuropharmacology. 2010;59(3):172-9. doi: 10.1016/j. neuropharm.2010.05.003.

25. Rafalovich IV, Melendez AE, Plotkin JL, Tanimura A, Zhai $S$, Surmeier DJ. Interneuronal nitric oxide signaling mediates post-synaptic long-term depression of striatal glutamatergic synapses. Cell Rep. 2015;13(7):1336-42. doi: 10.1016/j. celrep.2015.10.015.

26. Moncada S, Palmer RM, Higgs EA. Nitric oxide: physiology pathophysiology, and pharmacology. Pharmacol Rev. 1991;43(2):109-42.

27. Ulak G, Mutlu O, Akar FY, Komsuoğlu FI, Tanyeri P, Erden 
BF. Neuronal NOS inhibitor 1-(2-trifluoromethylphenyl)imidazole augment the effects of antidepressants acting via serotonergic system in the forced swimming test in rats. Pharmacol Biochem Behav. 2008;90(4):563-8. doi: 10.1016/j. pbb.2008.04.016.

28. Ghasemi M, Sadeghipour H, Mosleh A, Sadeghipour HR, Mani AR, Dehpour AR. Nitric oxide involvement in the antidepressant-like effects of acute lithium administration in the mouse forced swimming test. Eur Neuropsychopharmacol. 2008;18(5):323-32. doi: 10.1016/j.euroneuro.2007.07.011.

29. Finkel MS, Laghrissi-Thode F, Pollock BG, Rong J. Paroxetine is a novel nitric oxide synthase inhibitor. Psychopharmacol Bull. 1996;32(4):653-8.

30. Wagstaff A, Fitton A, Benfield P. Sulpiride: a review of its pharmacodynamic and pharmacokinetic properties, and therapeutic efficacy in schizophrenia. CNS Drugs 1994;2(4):313-33.

31. Jenner P, Marsden CD. Multiple dopamine receptors in brain and the pharmacological action of substituted benzamide drugs. Acta Psychiatr Scand. 1984;69(S311):109-23. doi: 10.1111/j.1600-0447.1984.tb06863.x.

32. Jenner P, Marsden CD. The mode of action of sulpiride as an atypical antidepressant agent. Adv Biochem Psychopharmacol. 1982;32:85-103.

33. Seeman P, Van Tol HH. Dopamine D4 receptors bind inactive $(+)$-aporphines, suggesting neuroleptic role. Sulpiride not stereoselective. Eur J Pharmacol. 1993;233(1):173-4. doi: 10.1016/0014-2999(93)90365-o.

34. Sampson D, Willner P, Muscat R. Reversal of antidepressant action by dopamine antagonists in an animal model of depression. Psychopharmacology (Berl). 1991;104(4):491-5. doi: $10.1007 /$ bf02245655.

35. Pucadyil TJ, Kalipatnapu S, Chattopadhyay A. The serotonin1A receptor: a representative member of the serotonin receptor family. Cell Mol Neurobiol. 2005;25(34):553-80. doi: 10.1007/s10571-005-3969-3.

36. Victor BS. Depression, antidepressants, and sexual function. Focus. 1995;10(9):5-6.

37. Hargrove V, Molina DK. A fatality due to cyproheptadine and citalopram. J Anal Toxicol. 2009;33(8):564-7. doi: 10.1093/ jat $/ 33.8 .564$.

38. Jia M, Li C, Zheng Y, Ding X, Chen M, Ding J, et al. Leonurine exerts antidepressant-like effects in the chronic mild stress-induced depression model in mice by inhibiting neuroinflammation. Int J Neuropsychopharmacol. 2017;20(11):886-95. doi: 10.1093/ijnp/pyx062.

39. Du L, Bakish D, Lapierre YD, Ravindran AV, Hrdina PD. Association of polymorphism of serotonin 2A receptor gene with suicidal ideation in major depressive disorder. Am J Med Genet. 2000;96(1):56-60. doi: 10.1002/(sici)10968628(20000207)96:1<56::aid-ajmg12>3.0.co;2-1.

40. Stuchlik A, Vales K. Role of alpha1- and alpha2-adrenoceptors in the regulation of locomotion and spatial behavior in the active place avoidance task: a dose-response study. Neurosci Lett. 2008;433(3):235-40. doi: 10.1016/j.neulet.2008.01.013.

41. Heninger GR, Charney DS, Price LH. alpha 2-Adrenergic receptor sensitivity in depression. The plasma MHPG, behavioral, and cardiovascular responses to yohimbine. Arch Gen Psychiatry. 1988;45(8):718-26. doi: 10.1001/ archpsyc. 1988.01800320028003.

42. Price LH, Charney DS, Rubin AL, Heninger GR. Alpha 2-adrenergic receptor function in depression. The cortisol response to yohimbine. Arch Gen Psychiatry. 1986;43(9):84958. doi: 10.1001/archpsyc.1986.01800090035006.

43. Millan MJ, Newman-Tancredi A, Audinot V, Cussac D, Lejeune F, Nicolas JP, et al. Agonist and antagonist actions of yohimbine as compared to fluparoxan at alpha(2)-adrenergic receptors $(\mathrm{AR}) \mathrm{s}$, serotonin (5-HT)(1A), 5-HT(1B), 5-HT(1D) and dopamine $\mathrm{D}(2)$ and $\mathrm{D}(3)$ receptors. Significance for the modulation of frontocortical monoaminergic transmission and depressive states. Synapse. 2000;35(2):79-95. doi: 10.1002/ (sici) 1098-2396(200002)35:2<79::aid-syn1>3.0.co;2-x.

44. Green B. Post-traumatic stress disorder: new directions in pharmacotherapy. Adv Psychiatr Treat. 2013;19(3):181-90.

45. Husain BF, Nanavaty IN, Marathe SV, Rajendran R, Vaidya VA. Hippocampal transcriptional and neurogenic changes evoked by combination yohimbine and imipramine treatment. Prog Neuropsychopharmacol Biol Psychiatry. 2015;61:1-9. doi: 10.1016/j.pnpbp.2015.03.004.

46. Stone EA, Quartermain D. Alpha-1-noradrenergic neurotransmission, corticosterone, and behavioral depression. Biol Psychiatry. 1999;46(9):1287-300. doi: 10.1016/s0006-3223(99)00234-6.

47. Arnsten AF, Rubia K. Neurobiological circuits regulating attention, cognitive control, motivation, and emotion: disruptions in neurodevelopmental psychiatric disorders. J Am Acad Child Adolesc Psychiatry. 2012;51(4):356-67. doi: 10.1016/j.jaac.2012.01.008.

48. Zarrindast MR, Ghiasvand M, Homayoun H, Rostami P, Shafaghi B, Khavandgar S. Adrenoceptor mechanisms underlying imipramine-induced memory deficits in rats. J Psychopharmacol. 2003;17(1):83-8. doi: $10.1177 / 0269881103017001709$.

49. Howland RH, Rush AJ, Wisniewski SR, Trivedi MH, Warden D, Fava $\mathrm{M}$, et al. Concurrent anxiety and substance use disorders among outpatients with major depression: clinical features and effect on treatment outcome. Drug Alcohol Depend. 2009;99(1-3):248-60. doi: 10.1016/j.drugalcdep.2008.08.010.

50. Drevets WC, Furey ML. Replication of scopolamine's antidepressant efficacy in major depressive disorder: a randomized, placebo-controlled clinical trial. Biol Psychiatry. 2010;67(5):432-8. doi: 10.1016/j.biopsych.2009.11.021.

51. Tenore PL. Psychotherapeutic benefits of opioid agonist therapy. J Addict Dis. 2008;27(3):49-65. doi: 10.1080/10550880802122646.

52. Lutz PE, Kieffer BL. Opioid receptors: distinct roles in mood disorders. Trends Neurosci. 2013;36(3):195-206. doi: 10.1016/j.tins.2012.11.002.

53. Grella SL, Funk D, Coen K, Li Z, Lê AD. Role of the kappaopioid receptor system in stress-induced reinstatement of nicotine seeking in rats. Behav Brain Res. 2014;265:188-97. doi: $10.1016 /$ j.bbr.2014.02.029.

54. Crowley NA, Kash TL. Kappa opioid receptor signaling in the brain: circuitry and implications for treatment. Prog Neuropsychopharmacol Biol Psychiatry. 2015;62:51-60. doi: 10.1016/j.pnpbp.2015.01.001.

55. Tejedor-Real P, Mico JA, Maldonado R, Roques BP, GibertRahola J. Implication of endogenous opioid system in the learned helplessness model of depression. Pharmacol Biochem Behav. 1995;52(1):145-52. doi: 10.1016/00913057(95)00067-7. 